OLEKSANDR HORBAN,

Borys Grinchenko Kyiv University (Kyiv, Ukraine)

e-mail: o.horban@kubg.edu.ua, ORCID0000-0003-2321-5963

RUSLANA MARTYCH,

Borys Grinchenko Kyiv University (Kyiv, Ukraine)

e-mail: r.martych@kubg.edu.ua,ORCID0000-0002-7755-4496

\title{
THE PHENOMENON OF HISTORICAL MEMORY IN THE CONTEXT OF THE GENESIS OF HISTORICAL METHODOLOGY
}

\begin{abstract}
The article analyzes the phenomenon of historical memory and approaches to its study in contemporary scientific discourse. It is stated that its emergence is associated with methodological transformations in the historical science of the last two centuries. Initially, in the course of theoretical research, historical memory was understood as a way of reconstructing the past, when an ethnos or a separate social group builds an image of the past to please the present. As a result of the crisis of traditional historiography, caused by the postmodern criticism of metanarratives, a re-actualization of historical memory occurs. In practice, this occurs in the form of mass commemorations, museumification of common and individual historical heritage, and the creation of an infrastructure for memorial tourism. Historical memory reveals its capabilities to form person's identity and life guidelines, rooted in the fundamental and universal function of human memory. An important feature of the contemporary research situation is that the rise of historical memory occurs in a crisis of the idea of objectivity and faith in the future. The current stage in the development of historical consciousness gives a new characteristic associated with the general nature of changes concerning various layers and forms of memory, as well as with the collapse of world history and structural changes in historical representations.
\end{abstract}

Key word: history; memory; methodology; historiography; historical memory; politics of memory.

\section{Introduction}

In the second half of the twentieth - early twenty first centuries, after the events of the Second World War and the tragedies connected with it, a rethinking of the role of historical science takes place. Awareness of the danger of using history as a tool of aggressive political propaganda led to the development of new directions in historical science - social and cultural history. It was during this period that the theory of memory (memoria studies) branched out as an independent direction of social and humanitarian research.

1980 became the symbolic borderline, which France, England and Brazil independently declared the year of heritage. The concept of heritage is firmly included in the lexicon of politicians, journalists, and cultural figures. In the 1980 s and 1990s, a wave of commemorations - solemn celebrations of memorable dates - swept around the world: the 200th anniversary of the French Revolution, the 500th anniversary of the discovery of America, the 1000th anniversary of the baptism of the countries of Northern and Eastern Europe (including Ukraine, part of the then USSR).

A separate "heritage industry" - the infrastructure of memorial tourism - is gradually being created. Many new museums and memorial complexes are opening at the sites of former battles or archaeological sites. Museumification and commercialization of the past are taking place on an unprecedented scale. "Public history" and "Historical preservation" appear in the curricula of history departments, especially in those universities that focus on the local labor market.

At the same time, the interest of ordinary people in the history of their family, profession, city, and region is growing. Amateur historians are allowed into the reading rooms of the archives, and history turns into "mass activity" (Samuel, 1994 : 25). Historical literature is becoming an increasingly popular form of mass reading, and historical films about the past are having a box office success.

Interest in heritage cannot but be linked to the revival of interest in religions, both traditional and new. Religious fundamentalism, mixing with political, is becoming an important factor in the domestic and foreign policy of many countries. Also a new factor was the rise of nationalism, which was perceived as a piquant, "nostalgic" peculiarity of specific regions such as Brittany or Catalonia in the 1970s, and became an influential political trend in many countries already in the 1990s. National and religious affiliations are beginning to be perceived with renewed vigor as an important factor of "identity" along with social status.

The new relevance of the problem of nationalism leads to a revival of interest in it in social theory. In the 1980 s, along with the main works on the history of memory, there are classic works on nationalism by Ernst Gellner (1991), Eric Hobsbawm, Benedict Anderson and others. The past also invades politics. In 1980, German 
Chancellor Helmut Kohl first used the phrase "historical politics" (Geschichtspolitik). This was a reaction to considerable debates about the past, in particular about $\mathrm{Na}$ tional Socialism and cooperation with it. In Eastern Europe, the rise of national memory leads to the delegitimization of communist regimes and to a new "nationalization of the past". The rise of historical memory was noted by scholarly historians and associated with the crisis of history as a scientific discipline.

According to leading scientists, the main reasons for this were:

- disillusionment with "big narratives" and with the "noble dream" of historical objectivity;

- "shredding of history", loss of the common language of the "subculture";

- since the 1980s, a sharp decrease in circulation of "professional" books on history;

- the decline of historical education and the weakening of the control of professional historians over collective ideas about the past;

- entry of new players in the "field of history": politicians, journalists, writers, filmmakers;

- the emergence of various "memory groups", first of all - ethnic and religious communities, which turned out to be much more active than the "social-class" memory groups.

It is these new players who direct and carry out the "expansion" into a new historical culture today. It relies on the juxtaposition of immediate, personal and emotional perception of the past, which is often associated with memory, which claims to be objective, but in reality is an ideologically biased history and creates even wider opportunities for political manipulation.

\section{Methodological basis of the research}

The fundamental work by M. Halbwachs "The Social Framework of Memory" (Halbwachs, 2007) is considered the beginning of systemic theoretical studies of historical memory. The main idea of the scientist was that historical memory is formed under the influence of social factors. And this applies not only to collective memory, but also to individual memory. Distinguishing them, the author shows the difference in the mechanisms of their interaction. According to M. Halbwachs, the memory of individuals can stand the test of time only because it is based on a social context. Without it, individual memories of the experience quickly disappear. To identify the social conditioning of memory M. Halbwachs introduces the concept of the "social framework", which he characterizes as "elementary and stable framework of collective memory" (Halbwachs, 2007: 318).

Memory is interpreted as a way of reconstructing the past. The social group builds the image of the past according to the requirements of the present and according to its own rules. Social shifts entail a change in the "social framework" of memory, and then inevitably lead to its reconfiguration. Analyzing the properties of collective memory, M. Halbwachs establishes its close connection with tradition, reveals its mythological nature.

The problematization of historical memory occurs under the influence of the introduction of new methods of historiography into circulation. In the 60 s and 70 s of the twentieth century, historiography flourished, as well as social sciences in general, which were characterized by a technocratic belief in progress and the imminent "death of the past", that is, in a decisive break with traditional society, in the words of Peter Laslett, with "the world that we have lost" (Laslett, 2005). The renowned historian J.H. Plumb wrote in 1969: "The power of the past is weakening in all spheres of public and private life. (...) Industrial society (...) does not require a past. Intellectually and emotionally, it focuses more on change than on conservation (...) The past turns into an object of curiosity, nostalgia, sentimental attachment" (Plumb, 1969: 14$15,60-61)$. In his opinion, scientific history should soon supplant the historical memory of society. But after a decade, completely different assessments became typical. One of the pioneers in the study of historical memory, the American historian David Lowenthal, noted: "The past is not dead at all, as J.H. Plumb. (...) From a modernist point of view, industrial and post-industrial society does not need to rely on outdated traditions, and modern science of history frees us from the tyranny of the past. However, the nostalgia that has taken possession of us, the manic search for origins, the craze for historical conservation, a strong attachment to the national heritage all this shows how intensely we still feel the past" (Lowenthal, 2015: XXIV-XXV). The problem of memory came to the fore in public life and scientific research.

Today, historical memory is becoming one of the central topics of the social sciences (Klein, 2000: 127-150; Kansteiner, 2002: 180). Researchers have proposed various, sometimes mutually exclusive, explanations for the rise of memory. "Acceleration of history" gives rise to nostalgia of break with traditional society. In the domestic scientific discourse, it is worth noting the emergence of works that focus on the need to institutionalize historical memory (Dodonov, 2018: 98-102). In addition, the theoretical and methodological foundations of the study of historical memory are being developed (Horban, Martych, 2019: 10-23). Considerable attention is paid to the phenomenon of historical trauma (Dodonova, 2019: 45-51; Dodonova at all, 2019: 153-164).

The purpose of this article is to analyze the formation and development of the phenomenon of historical memory as a logical continuation of methodological transformations in historical science.

\section{Results and Discussion}

Historical memory as an independent topic for research was established together with postmodernist approaches to history as a new source for creating historical sense. It revealed the possibilities rooted in the fundamental and universal function of memory as a means of forming an identity and life orientation.

The study of historical memory soon ceased to be the exclusive prerogative of historical science. The mechanisms of collective memory functioning began to be studied by sociologists and psychologists; means of relaying ideas about the past - by specialists in cultural anthropology; reconstruction of the past reality in works of art - by philologists and art critics etc.

The problem has gained such wide popularity that, according to the French historian Pierre Nora, the end of the 20th century can be described as "the era of the worldwide celebration of memory" (Nora, 2005), when issues of historical heritage and perception of the past became relevant for various communities - states, communes, collectives etc.

One of the manifestations of presentism was the reduction of the past to "recent history" or "histoire du temps present", the interest in which was inseparable from the interest in historical memory and was formed almost sim- 
ultaneously with it. Recent history is one of the fastest growing areas of historical research today.

At the same time, the "anti-positivist revolt" caused a radical reassessment of the possibilities of historical description. Now, the goal of historical cognition is not the objective reality, but the identification of the ways by which people of the past endowed their actions with meanings, the motives that guided them etc. An active search for sources, with the help of which the researcher can interpenetrate into the consciousness of an individual distant from him in time, begins. Myth, epos, memories as artifacts of human memory become the object of historian's research, an invaluable source of information about the past. The spheres of memory and history begin to overlap more and more. They necessarily assign the central place to political history, although, of course, they are not limited to it. In the center there is the tragedy of the Second World War and totalitarian regimes. Within this framework, the impossibility of avoiding moral judgments is especially acute. Even if historians have a method to establish facts with a high degree of accuracy at their disposal, they remain dependent on ideology in interpreting them. However, this dependence can take many forms. Ideology can be expressed both in direct political assessments and in an outwardly unbiased presentation of facts. Or it can be embedded in the formal structures of historical narrative. As for moral assessments of the past, modern historiography has come to realize their necessity, both thanks to the rise of historical memory and the study of "recent history", and also due to the "return of the subject" and interest in the role of feelings.

The most influential theory of modern historical memory is the concept of "places of memory" by Pierre Nora. From his point of view, "history is a national novel" and it is intellectually impossible in the contemporary world. Firstly, "Renan's nation is dead and will never rise again". The moment of the formation of nation states and their legitimization with the help of history is irrevocably gone. Secondly, after the collapse of the global "functionalist paradigms" in the social sciences (such as, for example, Marxism and structuralism), historians are unable to create a holistic picture of historical evolution and explain its causes. Therefore, memory "lurking in the places" that make up our existence - material objects turned into cultural symbols - is replacing history today. But this is no longer a "natural" memory of social groups passed down from generation to generation. Modernization has led to radical changes in the social structure and to the disappearance of groups - carriers of natural memory. As a result of the "acceleration of history," we have lost our natural connection with the past. Hence our interest in memory: "They talk so much about memory because it no longer exists" (Nora at all, 1999: 17). And, nevertheless, memory is everywhere - artificial, constructed with the lively participation of historians, but not subject to science. It has become a product of political manipulation, state rituals and cults, which are transmitted into the public consciousness through the education system, literature, art, and the press. Modern mass perceptions of history "dress up in the clothes" of natural memory, but in fact are the creation of professional agents of historical politics. "What we call memory today is no longer memory, but history", P. Nora writes (Nora at all, 1999: 28).

However, it is not quite a history, since it loses the structure of a linear story inherent in the latter. Such "his- tory-memory" as a form of contemporary experience of the past is, according to researchers, the only legitimate subject of historical research today. "Historians cannot explain the past. They can only show how the idea of it is formed and is functioning in the present (which, by the way, is an excellent exercise for the development of critical thinking)" (Koposov, 2011: 46-47).

Historical memory is a very dynamic segment of social consciousness. Static, once and for all, memory does not exist. This provision has an extremely important political dimension, since it disavows the incorrect, inherently marginal, attitude towards the "conservation" of the past, refusal to revise and rethink it. Social and political transformations inevitably lead to the reconfiguration of memory.

In the process of identifying the mechanisms for the formation of ideas about the past, including at the level of mass consciousness, the attention of scientists was attracted by the political component of this mechanism. Postmodern historians became interested in memory as a means of mobilizing political power. Therefore, in historical works focused on the problems of historical memory, the topic of "memory politics" is sufficiently developed: the study of the role of a political project, an order for the formation and consolidation of values, knowledge about the past with a specific socio-political goal. Analyzing specific plots, researchers are looking for an answer to a theoretical question: how a social idea of the past is created and national symbols are formed?

The famous Italian researcher $M$. Ferretti notes the following in this regard: "The problem is that memory, by itself, like the past, does not exist. It is always a construction, the result of continuous and imperceptible activity, conscious, and sometimes unconscious interaction of numerous people and multidirectional forces, which again and again weave the airy veil of the past. Paradoxically, there are as many types of memory in society as there are individuals, families, social groups, clans. Memory is multiple, and often its different manifestations are divided and conflict with each other. And, nevertheless, it is not difficult to observe what is naturally called memory, as a set of ideas about the past, which in a given society, at a given historical moment, becomes dominant and forms something like "common sense", which is shared by the majority. What is meant by memory acts as one of the sources of national identity, that is, a sense of belonging to a certain community, which, thanks to its characteristic common places and myths, recognizes itself in a common past - and, therefore, in a common present" (Ferretti, 2005).

Here it is important to highlight two points that allow clarifying the situation regarding the characteristics of memory. Firstly, the connection between memory and national identity is shown and, secondly, the necessary status of such memory - to be the dominant or overriding memory - is noted. Dominant memory is the version (modus) of collective memory prevailing in a certain society which suits the pro-government political elites (the dominant subject), and is imposed on other members of society as an official interpretation of past events, in order to legitimize their own political goals and domination. To ensure the dominant status of a certain vision of the past, the political forces that are in power pursue a historical policy with extensive use of state's administrative and financial resources. With this approach, dominant memory acts as a tool for influencing individual and social 
consciousness, it is a means of social control, as well as a kind of manipulation of historical consciousness.

The presence of social groups capable of defending their right to memory, fighting for the approval of their version of memory in public space, testifies to the high level of development of civil society, the implementation of the principles of pluralism, the presence of a certain degree of freedom in the socio-political sphere. In a society where the content of collective memory is the result of competitive activity in the public sphere, the memory, which is constructed according to the canons of progovernment discourse, can be dominant, but it is not, generally, the only one. Under such conditions, various ways of developing the situation are possible: both to social destabilization and destruction of the existing identity, and to the movement towards the public coordination of various positions and interests in order to achieve consensus models of collective coexistence.

Objectivity in the process of reproducing the past, which for a long time was the highest rating for the work of a historian, ceases to be an unconditional principle. "Not a single historian" N. Yakovenko writes, "concluding facts in a certain integrity, is free from the "social order", that is, from the pressure of political, ideological, religious, patriotic, etc. conjunctures of his time and environment" (Yakovenko, 2002: 12-14). At all times, historians have been and remain direct participants in the formation of historical memory, since they create the historical canon, which should become the frame of mass perceptions of the past. Despite the fact that the vocation of historical science is to demythologize the past, historiography itself is a direct participant in myth-making.

In the opinion of many contemporary researchers, the "historical memory" concept today has acquired such a general meaning, in which the professional study of history is seen as being put at the service of memory. After all, history as a science becomes not just a part of collective memory, but also memory itself, forming a holistic narrative of national history in this combination. Taking this into account, historical memory is interpreted as a sociocultural phenomenon of collective understanding the past by human communities, a holistic image of history, which a particular social group identifies itself with.

Such an important property of historical memory as its axiological coloration should also be noted. Collective memory endows historical images with value content. As L. Nagorna notes, "historical memory" is genetically programmed for evaluation. It is characterized not only with recall and reproduction, but also with a kind of reflection of perception or non-perception, approval or condemnation. Each historical fact falls, as if under a spotlight, and becomes the object of careful analysis. In addition, this analysis is conducted, usually, by a biased person. Guided by person's own system of values, a person himself chooses a "starting point" in the approach to the era that he studies. And the inevitable "evaluative binarity" ("white - black", "good - bad") interferes with seeing halftones and nuances (Nahorna, 2008).

\section{Conclusions}

Thus, the aforementioned characteristics of historical memory, such as social conditioning, mythological nature, axiological coloration, dynamism, means of social control and the formation of identity and life orientation, create a powerful potential for discursive management of society, including through the use of manipulative technologies.
An important feature of the current situation is that the rise of historical memory is taking place in a crisis of the idea of objectivity and faith in the future. Therefore, the current stage in the development of historical consciousness does not just fit into the sinusoid of periods of focus on the future and fascination with the past. It provides some new characteristic associated with the comprehensive nature of the changes concerning various layers and forms of memory, as well as with the disintegration of world history and structural changes in the historical imagination.

\section{REFERENCES}

Dodonov, R. (2018). The Institutionalization of the Politics of Memory. Skhid, 1 (153): 98-102. DOI: https://doi.org/10.21847/1728-9343.2018.1(153).127537

Dodonova, V., Dodonov, R., Aleksandrova, O., Popovich, O., Omelchenko, Y. (2019). Strategy and Tactics of Behaviour of Subjects and Objects of Historical Trauma. Analele Universitătii din Craiova. Istorie, 36 (2): 153-164.

Dodonova, VI. (2019). Istorychna travma: sproba definitsiyi. Kulturolohichnyy visnyk: Naukovo-teoretychnyy shchorichnyk Nyzhnoyi Naddnipryanshchyny, 39 (1): 45-51. Retrieved from https://www.kvnn.org.ua/archives/year2019/issue39/article-39-06/ (In Ukrainian)

Ferretti, M. (2005). Neprimirimaya pamyat: Rossiya i voyna. Zametki na polyakh spora na zhguchuyu temu Neprikosnovennyy zapas. 2-3 (40-41). Retrieved from http://magazines.russ.ru/nz/2005/2/fere8.html (In Russian)

Gellner, E. (1991). Natsii i natsionalizm (translat. from Engl.). Moscow: Progress, 126 p. (In Russian)

Halbwachs, M. (2007). Sotsialnyye ramki pamyati (translat. from French). Moscow : Novoye izdatelsvo, 348 p. (In Russian)

Horban, O.V.; Martych, R.V. (2019). Geneza kontseptu «istorychna pamyat» $v$ konteksti transformatsiy istorychnoyi metodolohiyi In: Skladni pytannya istorychnoyi pam"yati u paradyhmi dialohichnosti kultur [Difficult questions of historical memory in paradigm og culture dialogue]. Bialystok: Wydawnictwo Bialoruskie towarzystwo historyczne, Kyyiv. un-t im. B. Hrinchenka: 10-23. (In Ukrainian)

Kansteiner, W. (2002). Finding Meaning in Memory: A Methodological Critique of Collective Memory Studies. History and Theory, 41 (2): 179-197. DOI: https://doi.org/10.1111/0018-2656.00198

Klein, K.L. (2000). On the Emergence of Memory in Historical Discourse. Representations, 69: 127-150. DOI: https://doi.org/10.2307/2902903

Koposov, N. (2011). Pamyat strogogo rezhima. Moscow Novoye literaturnoye obozreniye, 320 p. (In Russian)

Laslett, P. (2005). The World We Have Lost. London: Routledge, DOI: https://doi.org/10.4324/9780203563335

Lowenthal, D. (2015). The Past Is a Foreign Country (Revisited). Cambridge: Cambridge University Press. DOI:10.1017/CBO9781139024884.024

Nahorna, L. P. (2008). Rehionalna identychnist: ukrayinskyy kontekst. Kyiv : IPiEND imeni I. F. Kurasa NAN Ukrayiny, 405 p. (In Ukrainian)

Nora, P. (2005). Vsemirnoye torzhestvo pamyati. Neprikosnovennyy zapas. 2-3 (40-41). Retrieved from http://magazines.russ.ru/nz/2005/2/nora22.html (In Russian)

Nora, P., Osuf, M., Puimège, J. de \& Vinok, M. (1999). Mezhdu pamyatyu i istoriyey (transl. from French). In: Frantsiyapamyat [France-memory]. St. Petersburg : St. Petersburg State University. (In Russian)

Plumb, J.H. (1969). The Death of the Past. London: Palgrave Macmillan. DOI: https://doi.org/10.1007/978-1-349-00418-8

Samuel, R. (1994). Theatres of Memory, vol. 1. Past and Present in Contemporary Culture. New York: Verso. 1994.

Yakovenko, N. (2002). Odna Klio, dvi istoriyi. Krytyka. 12: 12-14. (In Ukrainian) 
Олександр Горбань,

Киівський університет імені Бориса Грінченка

e-mail: o.horban@kubg.edu.ua, ORCID 0000-0003-2321-5963

Руслана Мартич,

Київський університет імені Бориса Грінченка

e-mail:r.martych@kubg.edu.ua, ORCID 0000-0002-7755-4496

\section{ФЕНОМЕН ІСТОРИЧНОї ПАМ'ЯТІ В КОНТЕКСТІ ҐЕНЕЗИ ІСТОРИЧНОї МЕТОДОЛОГІї}

У статті аналізується феномен історичної пам'яті та підходи до його дослідження в сучасному науковому дискурсі. Стверджується, що його поява пов'язана $з$ методологічними трансформаціями в історичній науці останніх двох століть. Спочатку в ході теоретичних досліджень історична пам'ять розумілася як спосіб реконструкції минулого, коли етнос або окрема соціальна група вибудовує образ минулого на догоду теперішньому. Далі, внаслідок кризи традиційної історіографії, спричиненої постмодерністською критикою метанаративу, відбувається реактуалізація історичної пам'яті. На практиці це має вигляд масових коммеморацій, музеєфікації загальної та індивідуальної історичної спадщини, створення інфраструктури меморіального туризму. Історична пам'ять розкриває свої можливості щодо формування ідентичності й життєвих орієнтирів людини, вкорінених у фундаментальній і універсальній функції людської пам'яті. Важливою особливістю сучасної дослідницької ситуації є те, що підйом історичної пам'яті відбувається в умовах кризи ідеї об'єктивності та віри в майбутнє. Нинішній етап розвитку історичної свідомості дає нову якість, пов'язану із загальним характером змін, що стосуються різних пластів і форм пам'яті, а також з розпадом всесвітньої історії та структурними змінами в історичних уявленнях.

Ключові слова: історія; пам'ять; методологія; історіографрія; історична пам'ять; політика пам'яті.

(c) Oleksandr Horban, Ruslana Martych

Надійшла до редакції: 24.09.2020

Прийнята до друку: 15.10.2020 